
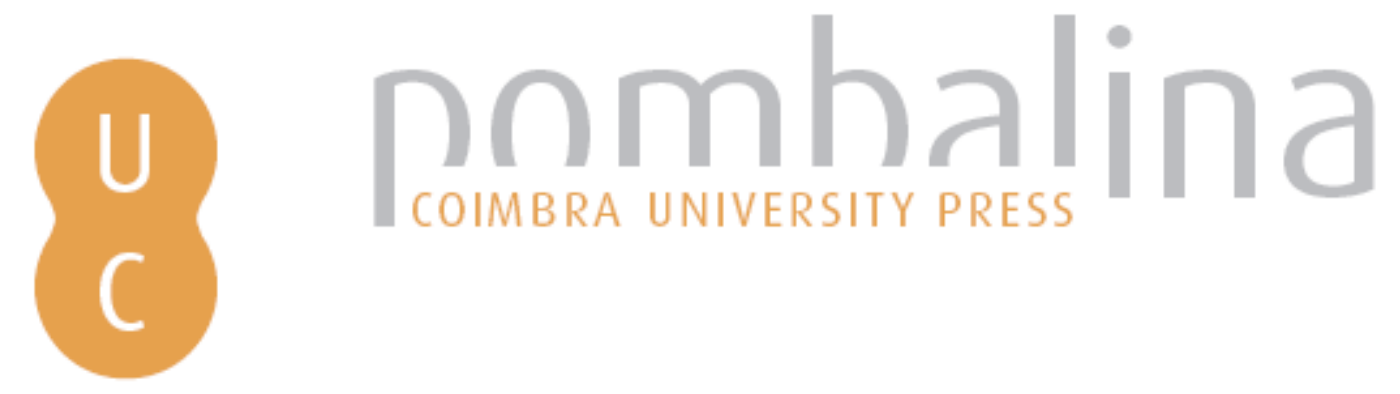

Aging, health and disease: the effect of religiosity on the optimism of elderly people

Autor(es): $\quad$ Mónico, Lisete dos Santos Mendes

Publicado por: Imprensa da Universidade de Coimbra

URL

persistente: URI:http://hdl.handle.net/10316.2/32543

DOI: $\quad$ DOI:http://dx.doi.org/10.14195/978-989-26-0732-0_20

Accessed : $\quad$ 26-Apr-2023 11:29:22

A navegação consulta e descarregamento dos títulos inseridos nas Bibliotecas Digitais UC Digitalis, UC Pombalina e UC Impactum, pressupõem a aceitação plena e sem reservas dos Termos e Condições de Uso destas Bibliotecas Digitais, disponíveis em https://digitalis.uc.pt/pt-pt/termos.

Conforme exposto nos referidos Termos e Condições de Uso, o descarregamento de títulos de acesso restrito requer uma licença válida de autorização devendo o utilizador aceder ao(s) documento(s) a partir de um endereço de IP da instituição detentora da supramencionada licença.

Ao utilizador é apenas permitido o descarregamento para uso pessoal, pelo que o emprego do(s) título(s) descarregado(s) para outro fim, designadamente comercial, carece de autorização do respetivo autor ou editor da obra.

Na medida em que todas as obras da UC Digitalis se encontram protegidas pelo Código do Direito de Autor e Direitos Conexos e demais legislação aplicável, toda a cópia, parcial ou total, deste documento, nos casos em que é legalmente admitida, deverá conter ou fazer-se acompanhar por este aviso. 
MPRENSA DA

UNIVERSIDADE

DE COIMBRA

COIMBRA

UNIVERSITY

- PRESS 


\title{
AGING, HEALTH AND DISEASE: THE EFFECT OF RELIGIOSITY ON THE OPTIMISM OF ELDERLY PEOPLE
}

\author{
Lisete dos Santos Mendes Mónico ${ }^{50}$
}

\begin{abstract}
In the aging process religiosity has been shown to be associated with important benefits. In this paper we seek to analyse the agency factors of religiosity in optimism and its mediation in satisfaction with life in both healthy and ill elderly people. The sample surveyed by the CROP Questionnaire, consisting of 376 Portuguese elderly people, 238 classified as healthy and 138 as ill, showed that there is a positive relationship between religiosity and optimism only for the group of healthy elderly people. For the ill elderly, optimism was only promoted by satisfaction with life. The distinction between optimism of internality and externality showed that the healthy elderly anchor their optimism in internality beliefs, while the ill elderly base their optimism on external factors. The establishment of a self-regulating system is discussed with beliefs and religious practices as perpetuators. Confrontation with personal frailty, powerlessness, and fear were discussed as predetermining factors to disembedding, as described by Giddens (1991, 1997), while reembedding occurs with the elderly regaining self-control, as a result of divine factors prone to optimism.
\end{abstract}

Keywords: Religiosity; Optimism; Healthy elderly; Ill elderly.

"The religious phenomenon, although complex, is a very important factor for understanding different human societies, in time and space,

50 Faculty of Psychology and Educational Sciences of the University of Coimbra Email: lisete_monico@fpce.uc.pt; IPCDVS 
because all of them, in one way or another, have been shaped by religious thought" (Rodrigues, 2007, p. 171). Religion performs vital functions in such a way that it becomes inseparable from human existence (McCullough \& Willoughby, 2009). Considering the analysis of the roles of religiosity and its impact on health, risk behaviours, and well-being as classic, research about the impact of religiosity on optimism in the elderly has been neglected. In this paper we compare the differences in religiosity and optimism of both healthy and hill elderly people. In addition, we analyse the impact that religiosity has on the optimism of both and we evaluate the mediating role of life satisfaction.

\section{Religiosity}

It is understood that religiosity is the individual level of commitment to beliefs, doctrines and practices of a religion (Baker \& Warburg, 1998; Mookherjee, 1994). The counterpart expression of religious experience (Geerts, 1990), it concerns the extent to which an individual believes, follows, and practices a religious doctrine, viewed between its two regulating poles: beliefs and rites. James (1902/1985) defines it as "a set of feelings, acts and experiences of the individual (...) while situated in a relation which he considers divine" (p. 50). This can be introduced either in a traditional way, in a formal and non-reflective way and obeying customs, or in an individual way, looking for answers to questions, needs, ideas and ideals (Grom, 1994).

Both religion and religiosity have an expression resulting in spirituality, namely, recognition of a non-material force that transcends all affairs, human and nonhuman, materialized in the search for meaning, unity, and human transcendence (Hill \& Pargament, 2003; Pargament, 1997). The concepts of spirituality and religion share a considerable overlap (Taylor, 1998), where we do not find existing consensus related to the conceptual delimitation of the former (Barros, 2000). Although many authors refer to religiosity using the term spirituality, the first differs from the latter by reference to a specific doctrinal system of 
worship of a god and/or other deities, shared with a group (Koenig, 1998; Yuen, 2007).

At the birth of the contemporary era, Houf (1945) pointed out the following functions of religion: ensuring superhuman help to individuals, depicting the nature and the problem of evil in societies, enabling a path to salvation, integrating the personality, providing opportunities for understanding and acceptance of life's meaning, gain mastery over oneself, being a model of individual and group life, and upholding moral values. More recently, Pargament, Koenig, and Perez (2000) summarize the functions of religion in attributions of meaning and control, intimacy, and comfort, associated with spirituality and life transformation.

\section{Optimism}

"No one doubts the importance of optimism for the happiness of people, for their physical and mental health, and also for their professional success" (Barros, 2004, p. 98). Also regarded as a belief, optimism refers to expectations of good results: "optimists are people who expect good experiences in the future. Pessimists are people who expect bad experiences" (Carver \& Scheier, 2000, p. 31). The tendency towards the positive, the expectation of future success, and the explanation given to negative events generally characterize optimism detected in such diverse areas of life as health, academic or professional achievement, interpersonal relationships and security (Buunk, 2001; Hoorens, 1994; McKenna, 1993; Simonds, 2005; Weinstein, 1982, 1983). The conceptual definitions orientate themselves to positive expectations, usually generalized and stable, demonstrating that people consider themselves, generally, slightly happier than others; they show a positive asymmetry in respect to distribution of positive experiences, as opposed to an opposite asymmetry for the experiencing of negative events (Scheier \& Carver, 1985, 1992; Tiger, 1979; Weinstein, 1980, 1983, 1984, 1989).

Regarding the subject, when we speak about the "stable tendency to believe that good instead of bad situations will happen" (Scheier \& Carver, 
1985, p. 219), we refer to the absolute or dispositional optimism, that is, to widespread expectations of achieving good results in the individual confrontation with problems in important life areas (Scheier \& Carver, 1992), differentiating from social or situational optimism (Barros, 2001, 2004). This kind of optimism, having an influence on the set of expectations in a stable and consistent way across situations and reflected in the tendency to establish positive predictions about results for the individual, is seen as a personality trait, a disposition or attitude that positive results will arise from for the individual, regardless of individu-

al abilities (Carver \& Scheier, 2000; Scheier \& Carver, 1985), adding to widespread expectations of getting few or no negative results (Scheier \& Carver, 1992).

The conception of dispositional optimism, dealing with general events and not focusing on specific perceived differences between the self and the others (Chang, 1998, 2000; Scheier \& Carver, 1985), emerges as the most present in literature, concomitant with the observation that people predict, in comparison with others, that they will experience a greater number of positive situations and fewer related to negative outcomes (Peeters, Czapinski, \& Hoorens, 2001; Shepperd, Carrol, Grace, \& Terry, 2002). This trend is known as comparative optimism (Weinstein, 1980, 1984, 1989).

\section{Satisfaction with life}

Life satisfaction is a complex phenomenon, difficult to measure because it is subjective. It evaluates the state of life of the individual in relation to his life in general and specific areas such as health, family, love relationships, economic conditions, social relations, autonomy, etc. (Joia, Ruiz, \& Donalisio, 2004; Mookherjee, 1994). It is a cognitive evaluation of the favourability of life according to pre-established criteria for the individual. Satisfaction with life, in general, reflects the overall assessment of subjective well-being of the individual, according to his own criteria. It refers to the perception of the individual about his position in life, 
within the context of his culture and values and in relation to his goals, expectations, standards and concerns (e.g., psychological concerns, levels of independence, social relationships, environmental characteristics, spiritual patterns; Moberg, 1984; Pavot \& Diener, 1993, 2008).

\section{Research problem and hypothesis}

There are known areas of life in which the elderly direct their aims: health, emotional balance, family, social adaptation. The behaviour of the elderly is determined by their aims, operating several self-regulatory mechanisms. Optimism enters in self-regulation when the elderly, although anticipating obstacles to achieving the goal of health, hold the conviction that they will be successful (Scheier \& Carver, 1992). Prediction based on Social Comparison Theory (Festinger, 1954) does not give optimism the widespread character that it has in literature (Alick, 1985; Carver \& Scheier, 2000), especially in old age, in which the adversities of life, such as health problems, are inevitable (Alloy \& Ahrens, 1987), sometimes leading to pessimism. In these situations, religious beliefs can take a key role in cognitive balance of the elderly, especially in the disease stage.

Believing in divine beings, with superhuman powers, is, among other things, a coping mechanism (Brown, 1987; Hinde, 2006; Pargament \& Mahoney, 2002) which, in times of difficulties and frustration, can promote optimism in the elderly. In this sense we hypothesize that religious beliefs, legitimated by reference to a tradition or a practice (Barros, 2000; Wallis \& Bruce, 1991), can be considered a determinant of optimism in the elderly, ill or healthy.

In our empirical study we want to analyse religiosity, optimism and satisfaction with life in healthy and ill elderly people. Three research hypotheses were formulated. Hypothesis 1: There is a positive correlation between the extent of religiosity and levels of optimism in the elderly. Hypothesis 2: The relationship between religiosity and optimism is mediated by individuals' satisfaction with life. 


\section{Internality and externality optimism}

The dichotomization internality / externality applied to optimism and pessimism led us to the development of the Hypothesis 3: The association between religiosity and optimism in the elderly will differ according to the anchor in internality or externality beliefs of optimism. As a basic premise of optimism anchored in internality beliefs is the expectation that desirable occurrences will happen via assignment of causality to factors internal to the individual, personal and dependent of himself. Inversely, individuals with optimism based on externality beliefs believe that their positive events will be determined by situational factors, external and not controllable by themselves, caused by others or determined by luck or by chance. Applying the concept of internality and externality to pessimism, we found the same reasoning. As the locus of control (Rotter, 1990), we consider that the continuum which goes from extreme optimism to extreme pessimism is permeated by internality or externality beliefs, and the anticipation of positive (optimism) or negative (pessimism) outcomes can be attributed to internal or external individual factors. Thus, by internality optimism we consider the expectation that good future experiences depend on their own personal skills. Externality optimism refers to the conviction that good results will prevail due to situational factors, with the elderly control not having over these factors, like luck or chance (Mónico, 2010).

\section{Method}

\section{Participants}

The study included 376 participants, surveyed through a self-administered questionnaire, of whom 238 are healthy elderly people $\left(M_{\text {age }}=74.87\right.$, $S D=6.77$ years, age range: $52-91$ years $)$ and 138 are ill $\left(M_{\text {age }}=68.92\right.$, $S D=10.35$ years, age range: $62-89$ years), all Portuguese citizens. The criterion established for considering an elderly person as ill or healthy 
was the establishment of two cut off points (up to the 25th percentile for the ill elderly and starting on the percentile 75 for the healthy elderly) in the responses to the question "how do you evaluate your state of health?", from 1 (totally sick) to 11 (completely healthy).

Eighty eight of the elderly (23.4\%) live in the northern region of the country, $243(64.6 \%)$ in the central region, $14(3.7 \%)$ in Lisbon and the Tagus Valley, 9 (2.4\%) in the Alentejo, 7 (1.9\%) in the Algarve, and 14 (3.7\%) in the Autonomous Regions of Madeira and Azores. Among the healthy elderly, 55 (14.6\%) are male and 183 (48.7\%) are female, while among the ill elderly $49(13.0 \%)$ are male and $89(23.7 \%)$ are female. Considering educational level, 55 (14.6\%) cannot read or write, 84 (22.3\%) can read and write without having the 4 th grade (corresponding to the 1st cycle of Basic Education), 123 (32.7\%) have the 4th grade, 28 (7.4\%) the 6 th grade, $30(8.0 \%)$ the 9 th grade, $14(3.7 \%)$ the 12 th grade, and 42 (11.1\%) higher education. We found 189 (50.3\%) married elderly people, $171(45.5 \%)$ widowed, 15 (4.0\%) divorced and 1 (0.3\%) single.

\section{Materials and Procedure}

We drew up the CROP Questionnaire - Portuguese acronym for Religious Beliefs, Optimism and Pessimism - duly treated with reliability and factorial analyses (Mónico, 2010). We established 3 indicators: Religiosity, Optimism, and Satisfaction with life. For the first one, Religiosity, we considered the following measures:

a) Attitudes and religious practices: [DEUS] 16 items, KR-20 $=.93$, unifactorial according to PCA) and Kind of beliefs [ACRE] (19 items, grouped into four factors according to PCA: F1-Christian beliefs, $\alpha=$ .95, F2- Paranormal/Occultism, $\alpha=.92, F 3$-Futurology, $\alpha=.85$, and F4Synesthesia, $\alpha=.81)$, all dichotomic $(0=$ does not apply to you and $1=$ applies to you), retrieved from Mónico (2010).

b) Orthodoxy, Tranquility and Religious Conflict Scale [OTCR]: 20 dichotomic items $(1=$ true and $0=$ false), retrieved from Moberg (1984), composed by two factors according to Principal Components Analysis 
(PCA), F1- Religiosity (internal consistency coefficient KR-20 = .94) and F2- -religiosity ( $(\mathrm{KR}-20=.80)$;

c) We also consider the following set of items (for a complete analysis, see Mónico, 2010): i) Multiple choice questions Belief in God [CREN] ( 1 = never believed to $4=$ always believed) and Level of Religiosity ( 1 = absolutely not religious to $7=$ extremely religious), retrieved from Cabral, Vala, Pais, and Ramos (2000); ii) Attitude towards religious expression and teaching [VORE]: two questions with seven response options ( $1=$ completely agree to 7 = completely against); iii) Attending courses / training programs of a religious nature [FRCA] e Use of iconographic objects [OBIC]: selection questions, composed by multiple choice categories unordered ( 0 = nor marked $; 1=$ marked $)$ regarding several courses and iconographic objects; iv) Frequency of prayer [CORE], retrieved form Fortuna and Ferreira (1992): one multiple choice question with six response options ( 1 = every day to 6 = never); v) Attribution of success to the belp of God [SUCE_Deus] one multiple choice question with seven response options ( 1 = strongly disagree to $7=$ strongly agree); vi) Attendance of religious advices [CONR], Influence of religion on time management [REIN], and Requests fulfilled in prayer [PEAT]: measures composed by a multiple choice question with five response options $(1=$ rarely $/$ none a $5=$ almost always/all).

For the indicator Optimism and Pessimism, we considered following measures:

a) Optimism [OISE]: 21 items, evaluated from 1 (strongly disagree) to 5 (strongly agree), adapted from Barros (1998), Scheier, Carver, and Bridges (1994), Schweizer and Koch (2001), Snyder et al. (1991) and Wiseman (2003), composed by three factors according to PCA (for a complete review, cf. Mónico, 2010): Internality optimism [OISE_F1] $(\alpha=$ .83), Openness to experience [OISE_F2] $(\alpha=.64)$, and Positive expectations [OISE_F3] $(\alpha=.67)$.

b) Estimation of future desirable events [POAC] - 24 items (measured from 0 to $100 \%$ ), retrieved from Wiseman (2003) composed by three factors according to PCA: Happiness, love, courage and luck [POAC_F1] $(\alpha=$ $.83)$, Physical attractiveness, admiration and success [POAC_F2] $(\alpha=.77)$, 
and Highly unlikely desirable event [POAC_F3] $(\alpha=.70)-$ and Wish for positive future events [DAPO]- the same items evaluating the wish for positive future events from 1 (almost never) to 7 (almost always).

c) Internality Pessimism [PESS]: 7 items, evaluated from 1 (strongly disagree) to 5 (strongly agree), adapted from Scheier et al. (1994), Schweizer and Koch (2001), and Snyder et al. (1991), unifactorial according to PCA.

d) Estimation of future negative events [PANE] - 21 items (measured from 0 to $100 \%$ ), retrieved from Mónico (2010) composed by three factors according to PCA: Depressive profile [PANE_F1] $(\alpha=.88)$, Fatalist profile [PANE_F2] $(\alpha=.86)$, and Victim profile [PANE_F3] $(\alpha=.66)-$ and Fear of negative future events [MANE] - the same items evaluating the fear of negative future events from 1 (I have no fear) to 7 (I am very afraid).

At last, for the indicator Satisfaction with life, we considered the multiple choice question Self-evaluation of current life [SITA](1 = very bad to 5 = very good), as well as the Perception of current problems [POPR] (adap. from Mónico, 2003; 15 items, KR-20 = .84) and the Satisfaction with life Scale [AVAP]: 17 adjectives with seven response options (0 = does not apply to me; to $7=$ applies to me).; unifactorial according to PCA, $\alpha=.91)$.

\section{Procedure}

After guaranteeing the anonymity and confidentiality of the answers, we requested the informed and voluntary consent of the elderly to answer the questionnaire. The questionnaires were administered by the author and a team of students coordinated by her as part of a research work for the discipline of Research Methods in Psychology I of the Master in Psychology, Faculty of Psychology and Educational Sciences of the University of Coimbra. The questionnaire was administered to the elderly mostly in a structured interview format by the interviewer team. We used 
SPSS 19.0 version for statistical data analysis. The process of construction and adjustment of measuring instruments, as well as the reliability and factorial analysis of the measures were treated in Mónico (2010).

\section{Results}

\section{Religiosity}

We made a standardization of the measures of the religiosity indicator, since they have different measurement scales, and held a Multivariate Analysis of Variance (MANOVA). We found that, in general, the healthy elderly are more religious than ill elderly, Wilks' $\Lambda=.840, F(17,3658)$ $=4.02, p<.001, \eta 2=.160,(1-\beta)>.999$. The univariate tests (see Table 17) show that the multivariate effect was due to all measures of the indicator Religiosity, except for Attending courses/training programs of a religious nature and beliefs in Paranormal/Occultism, Futurology, and Synesthesia. Among the most significant measures, we found the Level of religiosity, the Frequency of prayer, the factors Religiosity and A-religiosity (reversed score) from the scale Orthodoxy, tranquility and religious conflict, Attitudes and religious practices, and Christian Beliefs. We conclude that the healthy elderly are more religious than the ill elderly.

Table 17: Average standardized scores and standard-deviations of measures of Religiosity: Univariate tests

\begin{tabular}{|c|c|c|c|c|c|c|}
\hline \multirow{3}{*}{ Religiosity } & \multicolumn{4}{|c|}{ Elderly } & \multirow{3}{*}{$\begin{array}{c}\mathrm{F} \\
(1,374)\end{array}$} & \multirow{3}{*}{$\eta 2$} \\
\hline & \multicolumn{2}{|c|}{$\begin{array}{l}\text { Healthy } \\
(\mathrm{n}=238)\end{array}$} & \multicolumn{2}{|c|}{$\begin{array}{c}\text { Ill } \\
(\mathrm{n}=138)\end{array}$} & & \\
\hline & $\mathrm{M}_{\mathrm{z}}$ & $\mathrm{SD}_{\mathrm{z}}$ & $\mathrm{M}_{\mathrm{z}}$ & $\mathrm{SD}_{\mathrm{z}}$ & & \\
\hline [CREN] Belief in God & .16 & .71 & -.27 & 1.33 & $16.22^{* * * *}$ & .042 \\
\hline [RELI] Level of religiosity & .24 & .87 & -.42 & 1.08 & $42.70^{* * * *}$ & .102 \\
\hline [VORE] Attitude towards religious expression and teaching & -.08 & 1.00 & .13 & .99 & $3.95^{*}$ & .010 \\
\hline $\begin{array}{l}\text { [FRCA] Attending courses / training programs of a re- } \\
\text { ligious nature }\end{array}$ & .01 & 1.05 & -.02 & .90 & 0.07 & .000 \\
\hline [PEAT] Requests fulfilled in prayer & .16 & .95 & -.27 & 1.04 & $16.79^{* * * *}$ & .043 \\
\hline [CORE] Frequency of prayer & .23 & .73 & -.39 & 1.25 & $37.05^{\text {***** }}$ & .090 \\
\hline [OBIC_Obj] Use of iconographic objects & .08 & .93 & -.13 & 1.10 & $3.79 *$ & .010 \\
\hline
\end{tabular}




\begin{tabular}{|c|c|c|c|c|c|c|}
\hline \multirow{3}{*}{ Religiosity } & \multicolumn{4}{|c|}{ Elderly } & \multirow{3}{*}{$\begin{array}{c}F \\
(1,374) \\
\end{array}$} & \multirow{3}{*}{$\eta 2$} \\
\hline & \multicolumn{2}{|c|}{$\begin{array}{l}\text { Healthy } \\
(\mathrm{n}=238)\end{array}$} & \multicolumn{2}{|c|}{$\begin{array}{c}\text { Ill } \\
(\mathrm{n}=138)\end{array}$} & & \\
\hline & $\mathrm{M}_{\mathrm{z}}$ & $\mathrm{SD}_{\mathrm{z}}$ & $\mathrm{M}_{\mathrm{z}}$ & $\mathrm{SD}_{\mathrm{z}}$ & & \\
\hline [SUCE_Deus] Attribution of success to the help of God & .17 & .85 & -.29 & 1.16 & $19.25^{* * * *}$ & .049 \\
\hline [REIN] Influence of religion on time management & .14 & .92 & -.25 & 1.09 & $13.62^{* * * *}$ & .035 \\
\hline [CONR] Attendance of religious advices & .14 & .88 & -.24 & 1.14 & $13.04 * * *$ & .034 \\
\hline [DEUS] Attitudes and religious practices & .21 & .75 & -.36 & 1.25 & $29.62^{* * * * *}$ & .073 \\
\hline \multicolumn{7}{|l|}{ Kind of religious beliefs } \\
\hline [ACRE_F1] Christian Beliefs & .19 & .80 & -.33 & 1.21 & $25.16^{* * * * *}$ & .063 \\
\hline [ACRE_F2] Paranormal / Occultism & .03 & .98 & -.04 & 1.03 & 0.42 & .001 \\
\hline [ACRE_F3] Futurology & -.02 & .98 & .04 & 1.03 & 0.37 & .001 \\
\hline [ACRE_F4] Synesthesia & .00 & 1.01 & .00 & .99 & 0.00 & .000 \\
\hline \multicolumn{7}{|l|}{ Ortodoxy. tranquility and religious conflict } \\
\hline [OTCR_F1] Religiosity & .22 & .65 & -.38 & 1.34 & $34.10^{* * * *}$ & .084 \\
\hline [OTCR_F2] A-religiosity (reversed score) & .21 & .76 & -.36 & 1.24 & $30.50^{* * * *}$ & .075 \\
\hline
\end{tabular}

$* * * p<.001$

\section{Optimism and pessimism}

We standardized measures for the optimism and pessimism indicator and performed two MANOVAs, one for measures of optimism and one for pessimism. For measures of optimism, as expected, the result of the multivariate test indicated superiority in the healthy elderly, Wilks' $\Lambda=$ $.887, F(9,366)=5.18, p<.001, \eta 2=.113,(1-\beta)>.999$. Inversely, we found a superiority of pessimism in ill elderly, Wilks' $\Lambda=.896, F(7,378)$ $=6.07, p<.001, \eta 2=.104,(1-\beta)>.999$. Analysing the univariate tests (see Table 18), we found that the healthy elderly are more optimistic than the ill elderly in all measures (except Openness to experience), demonstrating higher scores in Internality Optimism, Estimation for positive future events related to Happiness, love, courage and luck, but also to Physical attractiveness, admiration, and success. However, the ill elderly wish for more positive future events concerning with happiness, love, courage, luck, physical attractiveness, admiration, success, and highly unlikely desirable events like winning the lottery.

As regards to pessimism, the ill elderly are more pessimistic, as we can see in Table 2. They estimate more future negative events related to 
depressive, fatalist, and victim profiles. They also show more fear about these future negative events.

Table 18: Average standardized scores and standard-deviations of measures of Optimism and Pessimism: Univariate tests

\begin{tabular}{|c|c|c|c|c|c|c|}
\hline \multirow{3}{*}{$\begin{array}{l}\text { Optimism and Pessimism } \\
\text { Measures: }\end{array}$} & \multicolumn{4}{|c|}{ Elderly } & \multirow{3}{*}{$\begin{array}{c}\mathrm{F} \\
(1.374)\end{array}$} & \multirow{3}{*}{$\eta 2$} \\
\hline & \multicolumn{2}{|c|}{$\begin{array}{l}\text { Healthy } \\
(\mathrm{n}=238)\end{array}$} & \multicolumn{2}{|c|}{$\begin{array}{c}\text { Ill } \\
(\mathrm{n}=138)\end{array}$} & & \\
\hline & $\mathrm{M}_{\mathrm{z}}$ & $\mathrm{SD}_{\mathrm{z}}$ & $\mathrm{M}_{\mathrm{z}}$ & $\mathrm{SD}_{\mathrm{z}}$ & & \\
\hline \multicolumn{7}{|l|}{ Optimism } \\
\hline \multicolumn{7}{|l|}{ [OISE] Optimism } \\
\hline [OISE_F1] Internality optimism & .16 & .97 & -.10 & 1.04 & $6.24^{* * * *}$ & .006 \\
\hline [OISE_F2] Openess to experience & -.05 & 1.01 & .08 & .97 & 1.33 & .004 \\
\hline [OISE_F3] Positive expectations & .08 & .95 & -.13 & 1.08 & $3.70^{*}$ & .010 \\
\hline \multicolumn{7}{|l|}{ [POAC] Estimation of future desirable events } \\
\hline [POAC_F1] Happiness. love. courage and luck & .23 & 1.01 & -.13 & .97 & $11.82^{* * * * *}$ & .031 \\
\hline $\begin{array}{l}\text { [POAC_F2] Physical attractiveness. admiration. } \\
\text { and success }\end{array}$ & .18 & 1.10 & -.10 & .93 & $6.85^{\text {*** }}$ & .018 \\
\hline [POAC_F3] Highly unlikely desirable event & .14 & 1.03 & -.08 & .97 & $4.33^{*}$ & .011 \\
\hline \multicolumn{7}{|l|}{ [DAPO] Wish for positive future events } \\
\hline [DAPO_F1] Happiness. love. courage and luck & -.17 & 1.02 & .30 & .89 & $20.72^{\text {*冰* }}$ & .052 \\
\hline $\begin{array}{l}\text { [DAPO_F2] Physical attractiveness. admiration. } \\
\text { and success }\end{array}$ & -.14 & .97 & .24 & 1.02 & $13.20^{* * * * * *}$ & .034 \\
\hline [DAPO_F3] Highly unlikely desirable events & -.08 & 1.03 & .13 & .94 & $3.78^{*}$ & .010 \\
\hline \multicolumn{7}{|l|}{ Pessimism } \\
\hline [PESS] Internality pessimism & -.12 & 1.00 & .20 & .97 & $8.83^{\text {*** }}$ & .023 \\
\hline \multicolumn{7}{|l|}{ [PANE] Estimation of future negative events } \\
\hline [PANE_F1] Depressive profile & -.20 & .90 & .35 & 1.08 & $28.09^{* * * * *}$ & .070 \\
\hline [PANE_F2] Fatalist profile & -.23 & .95 & .40 & .96 & $37.47^{\text {***** }}$ & .091 \\
\hline [PANE_F3] Victim profile & -.14 & .92 & .24 & 1.08 & $13.42^{\text {***** }}$ & .035 \\
\hline \multicolumn{7}{|l|}{ [MANE] Fear of negative future events } \\
\hline [MANE_F1] Depressive profile & -.13 & 1.00 & .23 & .95 & $11.51^{\text {****** }}$ & .030 \\
\hline [MANE_F2] Fatalist profile & -.16 & 1.02 & .27 & .91 & $16.31^{\text {****** }}$ & .042 \\
\hline [MANE_F3] Victim profile & -.10 & .95 & .17 & 1.06 & $6.34^{*}$ & .017 \\
\hline
\end{tabular}

* $p<.05, * * p<.01, * * * \quad p<.001$

\section{Test of research hypothesis}

\section{Hypothesis 1 and 2}

Hypothesis 1 points out the existence of a relation between the extent of religiosity and the levels of optimism. We built a structural equations 
model considering that the measures of the indicator Religiosity have a predictive effect on Optimism in healthy and ill elderly people. In addition, we evaluated the mediating role of satisfaction with life in the association religiosity-optimism, in order to test Hypothesis 2: The relationship between religiosity and optimism is mediated by individuals' satisfaction with life.

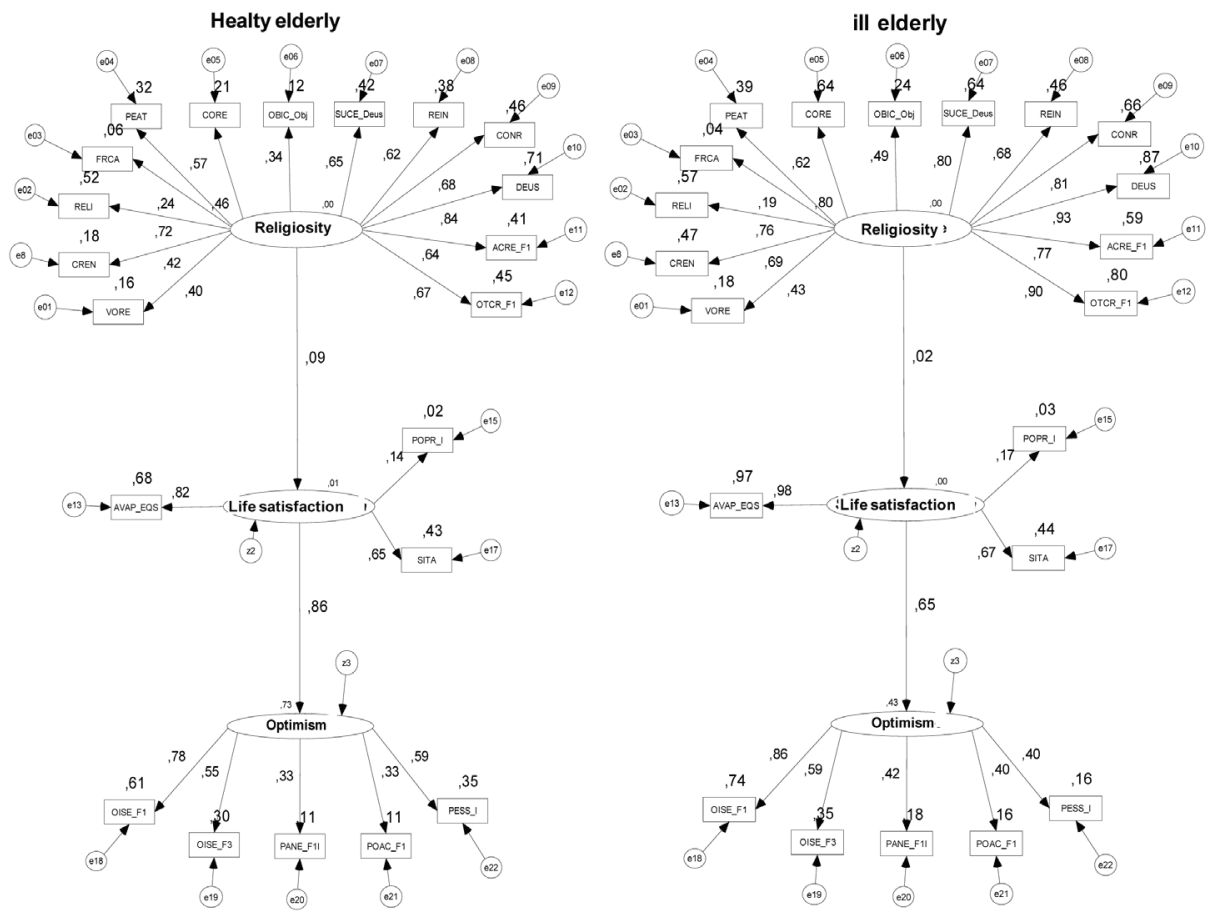

Key: Religiosity Indicator: Religiosity Indicator: [VORE] Attitude towards religious expression and teaching; [CREN] Belief in God; [RELI] Level of religiosity; [FRCA] Attending courses / training programs of a religious nature; [PEAT] Requests fulfilled in prayer; [CORE] Frequency of prayer; [OBIC_Obj] Use of iconographic objects; [SUCE_Deus] Attribution of success to the help of God; [REIN] Influence of religion on time management; [CONR] Attendance of religious advices; [DEUS] Attitudes and religious practices; [ACRE_F1] Christian Beliefs; [OTCR_F1] Orthodoxy, tranquility and religious conflict_Factor Religiosity.

Life Satisfaction Indicator: [AVAP_EQS] Satisfaction with life; [POPR_I] Perception of current problems (reversed score); [SITA] Self-evaluation of current life.

Optimism Indicator: [OPFF] [OISE_F1] Optimism and internality; [OISE_F3] Possibility of negative future events_Depressive profile; [PANE_F1] Depressive profile (reversed score); [POAC_F1] Happiness, love, courage and luck; [PESS_I] Internality pessimism (reversed score).

Figure 47: Multigroup structural equation modelling: Regression coefficients for the healthy and ill elderly 
After specifying the measurement model, we proceeded to the estimation and evaluation of the degree of adjustment, using AMOS 18.0 (see figure 47). The dependency relationships, developed between the latent constructs and observable variables, were based on the theoretical hypothesis that points to a positive relationship between religiosity and optimism (Mónico, 2010). We build a path diagram and we specified the model (Byrne, 2001; Kline, 2005; Schumacker \& Lomax, 1996), fixing the residual variance at zero (Hatcher, 1996). Thereby, a multigroup structural equation modelling was performed for the healthy and ill elderly, regarding the test of the two first research hypothesis, goodness of fit $C M I N / D F=3.26, \chi 2(417)=1358.55, p<.001, \mathrm{NFI}=.706, C F I=.787$, and RMSEA $=.068$.

We found that the optimism of healthy elderly people was significantly determined by their religiosity $(\beta=.09, p<.05$ for healthy elderly vs. $\beta=.02, p>.05$ for ill elderly), while for ill elderly people optimism is only promoted by satisfaction with life (see figure 47). Thus, Hypothesis 1 received empirical support only for the healthy elderly. Satisfaction with life was shown to be a mediator between religiosity and optimism, giving support to Hypothesis 2.

\section{Hypothesis 3}

According to the content of the items, we made a distinction between internality and externality measures of Optimism and performed a new multigroup structural equation modelling (see Mónico, 2010 for a detailed review). We considered the following measures for Internality Optimism: Internality optimism [OISE_F1], Openness to experience [OISE_F2], Depressive profile (reversed score) [PANE_F1], Happiness, love, courage and luck [POAC_F1], and Internality pessimism [PESS] (reversed score). For Externality Optimism we adopted the measures of: Positive expectations [OISE_F3], Highly unlikely desirable events [POAC_F3], Fatalist profile [PANE_F2] (reversed score), Physical attractiveness, admiration, and success [POAC_F2], and Victim profile [PANE_F3] (reversed score). 
Given the reference values of the goodness of fit (Bentler 1990; Schumacker \& Lomax, 1996), we concluded that the proposed structural model is adjusted: CMIN $\chi^{2}(188)=3.12(p<.001), N F I=.802, C F I=$ .889 and RMSEA $=.053$. The results are highlighted in Figures 48 and 49. When we compare the models considering internality and externality optimism, we found that the optimism of the healthy elderly is based on internality beliefs $(\beta=.09, p<.05$ for Internality Optimism vs. $\beta=$ $-.05, p>.05$ for Externality Optimism), as shown in Figure 48. On the other hand, the optimism of the ill elderly is more based on externality beliefs $(\beta=.01, p>.05$ for Internality Optimism vs. $\beta=.09, p<.05$ for Externality Optimism; see Figure 49).

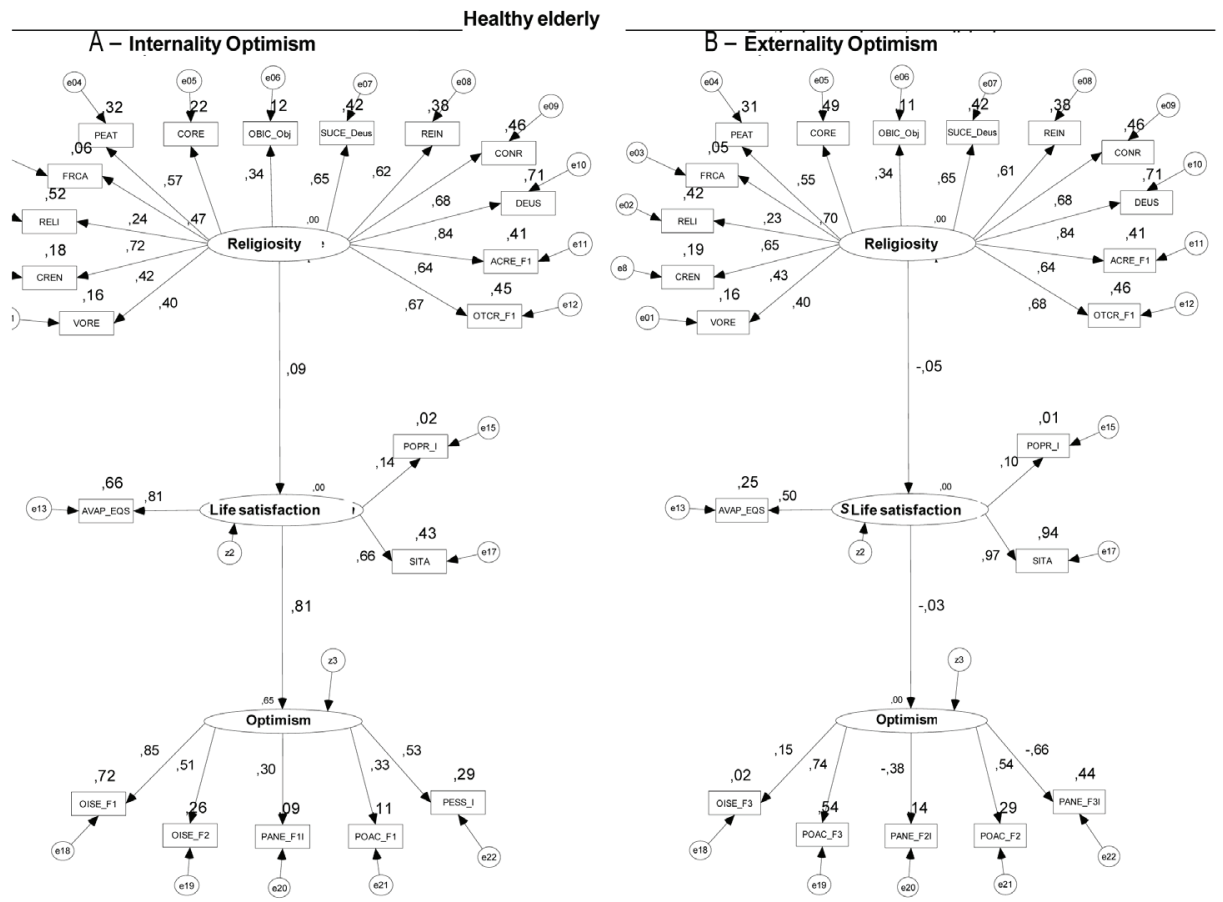

Key: Measures of Internality Optimism: [OISE_F1] Internality optimism; [OISE_F2] Openness to experience; [PANE_F1I] Depressive profile (reversed score); [POAC_F1] Happiness, love, courage and luck; [PESS_I] Internality pessimism (reversed score).

Measures of Externality Optimism: [OISE_F3] Positive expectations; [POAC_F3] Highly unlikely desirable event [PANE_F2I] Fatalist profile (reversed score); [POAC_F2] Physical attractiveness, admiration, and success; [PANE_F3I] Victim profile (reversed score).

For the remaining measures, see legend of Figure 47.

Figure 48: Multigroup structural equation modelling: Regression coefficients for healthy elderly 


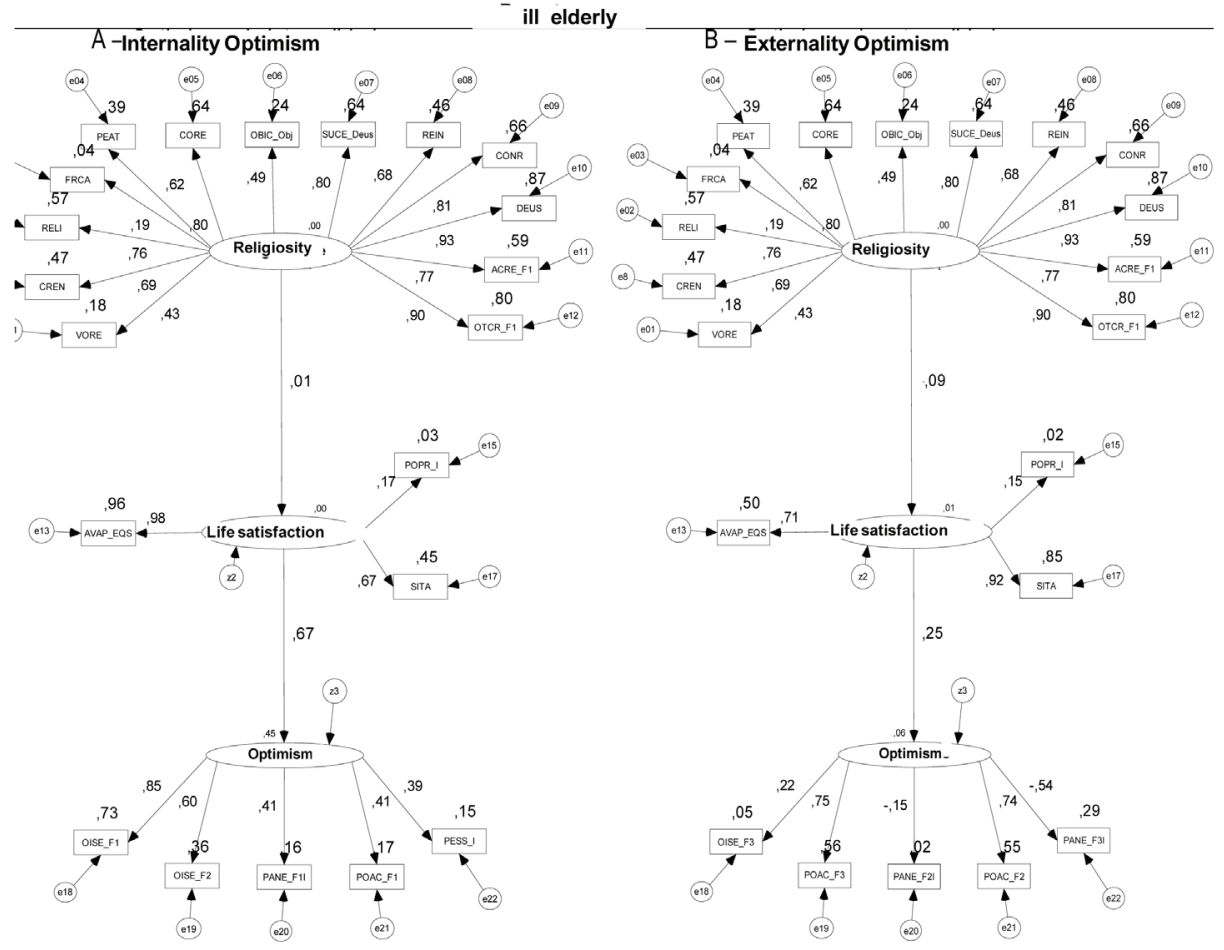

Note: see key of Figure 48

Figure 49: Multigroup structural equation modelling:

Regression coefficients for ill elderly

\section{Discussion}

In this article it was seen that the state of health or disease of the elderly showed clear effects on Religiosity and Optimism measures. In general, the healthy elderly are more religious and more optimistic than the ill elderly. Religiosity was found as an antecedent of optimism only in the healthy elderly, with the optimism of ill elderly being dependent on their satisfaction with life. The Hypothesis 1 found empirical support only in the healthy elderly, where religiosity promotes optimism. Satisfaction with life was found to be a mediator between religiosity and optimism, showing high correlations with optimism, supporting Hypothesis 2 in general. 
"Optimism is seen as a cognitive feature (a goal, an expectation, a belief or a causal attribution) about the desired and perceived as successful future" (Barros, 2004, p. 101). The distinction between internality and externality optimism (Hypothesis 3) has shown that the healthy elderly and ill elderly anchor their optimism in different kind of beliefs. Healthy elderly people anchor their optimism in internality beliefs, showing the model of forecasting the optimism based on externality beliefs totally insignificant. Inversely, the ill elderly base their optimism on external beliefs, showing religiosity as unable to predict optimism anchored in internality beliefs. This demonstrates the importance of distinguishing internal causes of external causes in the kind of beliefs underlying optimism.

Searching for an interpretation for these results, in recent decades researchers in positive psychology have come to recognize self-regulation as an important aspect of the self, such as resilience, adaptation to adversities (Barros, 2000; Brown, 1987; Higgins, Grant, \& Shah, 1999), or even spiritual and religious development (McCullough \& Boker, 2007; Pargament \& Mahoney, 2002). We consider that individuals can use beliefs and religious behaviours as a self-regulatory mechanism, which confers on them stability and promotes optimism. As McCullough and Boker (2007) state, "to a certain point, spiritual and religious changes can also be caused by self-regulatory processes that are intrinsic to the functioning of the individual" (p.385). The importance that each one gives religion is, in some way, ruled by the functioning of an internal orientation system that seeks to achieve internal balance.

Giddens $(1991,1997)$ draws attention to the disorientation of individuals currently forming social organizations as if they found themselves involved in a number of situations that they do not fully understand. For the author, in modern societies time and space do not blend, as social space is no longer confined by the set of boundaries of space in which people move. Given this distinction, events are ever-changing and occur at a fast rhythm; there are feelings of discomfort, fear and anxiety, consequences that Giddens called disembedding, in other words, "dislocation of social relationships of local interaction contexts and their restructuring by means of undefined extensions of time-space” (Giddens, 1991, p. 29). 
The personal frailty caused by old age and, specifically, the state of disease promotes disembedding, emerging the need to reduce tensions and reach security and self-control. The individuals develop mechanisms that seek to acquire security and reduce anxiety. These mechanisms, which Giddens calls reembedding, consist of "a way to establish trust in reliability and integrity of familiar people" (p. 90). Religiosity can be seen as a self-regulatory strength, a route of self-monitoring, and a coping strategy, enabling a new cognitive balance that promotes reembedding (Giddens, 1991, 1997). In these circumstances it is understandable that the healthy elderly are more religious than the ill elderly. A self-regulatory system is established, where beliefs and religious practices are promoters of optimism, anchored in internality beliefs for healthy elderly people, and in externality beliefs for the ill elderly.

\section{Limitations and future directions}

The main limitation noted for this study is the lack of an objective measure about the health condition of the participants. The measure used, based on self-perception of one's health condition, may have been influenced by the degree of optimism of the participants. Another limitation is the lack of distinction on the religious orientation of the participants, intrinsic or extrinsic, according to description of Allport and Ross (1967). An intrinsic religious orientation is characterized as something deeply personal, as "a motivating force that allows the individual to live his religion and not just use it as a means to an end" (Linares, 2012, p. 32), while an extrinsic orientation is focused on utilitarianism of religion while satisfying primary needs. It would be important in future studies to analyse the structural model of promoting internality or externality optimism by religiosity, given the religious orientation. A further direction of this study might be to measure the feelings of disembedding, in the sense of Giddens (1991, 1997), and examine how religiosity may constitute itself as a buffer effect of these feelings, and how the religious orientation of the participants, intrinsic or extrinsic, can contribute to reembedding. 


\section{References}

Alicke, M. D. (1985). Global self-evaluation as determined by the desirability and controllability of trait adjectives. Journal of Personality and Social Psychology, 49, 1621-1630.

Alloy, L. B., \& Ahrens, A. H. (1987). Depression and pessimism for the future: Biased use of statistically relevant information in predictions for self versus others. Journal of Personality and Social Psychology, 52, 366-378.

Allport, G. W., \& Ross, J. M. (1967). Personal religious orientation and prejudice. Journal of Personality and Social Psychology, 5, 432-443.

Barker, E., \& Warburg, M. (1998). (Eds.). New religions and new religiosity. Springfield, Ma: Aarhus University Press.

Barros, J. (1998). Optimismo: Teoria e avaliação. Psicologia, Educação, Cultura, 2(2), 295308.

Barros, J. (2000). Psicologia da religião. Coimbra: Almedina.

Barros, J. (2001). Optimismo: Uma perspectiva diferencial. Revista Portuguesa de Pedagogia, $35,101-117$.

Barros, J. (2004). Psicologia positiva. Porto: ASA.

Bentler, P. (1990). Multivariate analysis with latent variables: Causal modeling. Annual Review of Psychology, 31, 419-456.

Brown, L. B. (1987). The psychology of religious belief. London: Academic Press.

Buunk, B. P. (2001). Perceived superiority of one's own relationship and perceived prevalence of happy and unhappy relationships. British Journal of Social Psychology, $40,565-574$.

Byrne, B. M. (2001). Structural equation modeling with AMOS: Basic concepts, applications and programming. Mahwah, NJ: Erlbaum.

Cabral, M. V., Vala, J., Pais, J. M., \& Ramos, A. (2000). Atitudes e práticas religiosas dos portugueses. Lisboa: ISCTE.

Carver, C. S., \& Scheier, M. F. (2000). Optimism, pessimism, and self-regulation. In E. C. Chang (Ed.), Optimism and pessimism: Implications for theory, research, and practice (1st ed., pp. 31-51). Washington, DC: American Psychological Association.

Chang, E. C. (1998). Does dispositional optimism moderate the relation between perceived stress and psychological well-being: A preliminary investigation. Personality and Individual Differences, 25, 233-240.

Chang, E. C. (2000). Introduction: Optimism and pessimism and moving beyond the most fundamental question. In E. C. Chang (Ed.), Optimism \& pessimism: Implications for theory, research, and practice (1st ed., pp. 3-12). Washington, DC: American Psychological Association.

Festinger, L. (1954). A theory of social comparison processes. Human Relations, 7, 117-140 (translation in C. Faucheux \& S. Moscovici (1971). Psychologie sociale théorique et expérimentale. La Haye: Mouton).

Geerts, H. (1990). An inquiry into the meaning of ritual symbolism: Turner and Peirce. In H-G. Heimbrock \& H. B. Boudewijnse (Eds.), Current studies on rituals: Perspectives for the psychology of religion (pp. 19-32). Amsterdam: Atlanta, GA.

Giddens, A. (1991). Modernity and self-identity: Self and society in the late modern age. Cambridge: Polity.

Giddens, A. (1997). Sociology (3 ${ }^{a}$ ed.). Cambridge: Polity Press. 
Grom, B. (1994). Psicología de la religión. Barcelona: Editorial Herder.

Hatcher, L. (1996). A step-by-step approach to using the SAS system for factor analysis and structural equation modelling. Cary, NC: SAS Institute, Inc.

Higgins, E. T., Grant, H., \& Shah, J. (1999). Self-regulation and quality of life: Emotional and non-emotional life experiences. In D. Kahneman, E. Diener, \& N. Schwartz (Eds.), Well-being: The foundations of hedonic psychology (pp. 244-266). New York: Russell Sage.

Hill, P. C., \& Pargament, K. (2003). Advances in the conceptualization and measurement of religion and spirituality: Implications for physical and mental health research. American Psychologist, 58(1), 64-74. doi: 10.1037/0003-066X.58.1.64

Hinde, R. A. (2006). Why God persist: A scientific approach to religion. London and New York: Routledge.

Hoorens, V. (1994). Unrealistic optimism in social comparison of health and safety risks. In D. Rutter (Ed.), The social psychology of health and safety: European perspectives (pp. 153-174). Avesbury: Aldershot.

Houf, H. T. (1945). What religion is and does: An introduction to the study of its problems and values. New York: Harper \& Brothers.

James, W. (1985). The varieties of religious experience: A study in human nature.

Joia, L. C., Ruiz, T., \& Donalisio, M. R. (2004). Condições associadas ao grau de satisfação com a vida entre a população de idosos. Revista Saúde Pública, 41(1), 131-138.

Kline, R. B. (2005). Principles and practice of structural equation modeling ( $2^{\text {nd }} \mathrm{ed}$.). New York: The Guilford Press.

Koenig, H. G. (1998). (Ed.) Handbook of religion and mental health. San Diego: Academic Press.

Linares, R. (2012). O envolvimento religioso e a sintomatologia depressiva em imigrantes brasileiros. Lisboa: Faculdade de Psicologia [Doctoral Dissertation in Psychology (especiality in Clinical Psychology - 2012/10/19].

McCullough, M. E., \& Willoughby, B. L. (2009). Religion, self-regulation, and self-control: Associations, explanations, and implications. Psychological Bulletin, 135, 69-93. doi: $10.1037 / \mathrm{a} 0014213$

McKenna, F. P. (1993). It won't happen to me: Unrealistic optimism or illusion of control? British Journal of Psychology, 84, 39-50.

Moberg, D. O. (1984). Subjective measures of spiritual well-being. Review of Religious Research, 25, 351-359.

Mónico, L. S. (2003). Autopercepção da beleza física e estratégias de auto-apresentação em contextos de sedução. Unpublished Master's Dissertation', Faculdade de Psicologia e de Ciências da Educação da Universidade do Porto, Porto.

Mónico, L. S. (2010). Religiosidade e optimismo: Crenças e modos de implicação comportamental. Coimbra: Faculdade de Psicologia e de Ciências da Educação [Doctoral Dissertation in Psychology (especiality in Social Psychology) - 2010/10/12].

Mookherjee, H. N. (1994). Effects of religiosity and selected variables on the perception of well-being. The Journal of Social Psychology, 134(3), 403-405.

Pargament, K. I. (1997). The psychology of religion and coping: Theory, research and practice. New York: Guilford Press.

Pargament, K. I., \& Mahoney, A. (2002). Spirituality: Discovering and conserving the sacred. In C. R. Snyder \& S. J. Lopez (Eds.), Handbook of positive psychology (pp. 646-659). New York: Oxford University Press. 
Pargament, K. I., Koenig, H. G., \& Perez, L. M. (2000). The many methods of religious coping: Development and initial validation of the RCOPE. Journal of Clinical Psychology, 56(4), 519-543.

Pavot, W. \& Diener, E. (1993). Review of the satisfaction with life scale. Psychological Assessment, 2, 164-172.

Pavot, W. \& Diener, E. (2008). The satisfaction with life scale and emerging construct of life satisfaction. The Journal of Positive Psychology, 3, 137-152. doi: 10.1080/17439760701756946

Peeters, G., Czapinski, J., \& Hoorens, V. (2001). Comparative optimism, pessimism, and realism with respect to adverse events and their relationship with will to live. International Review of Social Psychology, 14(4), 143-162.

Rodrigues, D. (2007). Sociologia da religião: Uma introdução. Porto: Edições Afrontamento.

Rotter, J. B. (1990). Internal versus external control of reinforcement: A case history of a variable. American Psychologist, 45, 489-493.

Scheier, M. F., \& Carver, C. S. (1985). Optimism, coping, and health: Assessment and implications of generalized outcome expectancies. Health Psychology, 4, 219-247.

Scheier, M. F., \& Carver, C. S. (1992). Effects of optimism on psychological and physical well-being: Theoretical overview and empirical update. Cognitive Therapy and Research, 16, 201-228.

Scheier, M. F., Carver, C. S., \& Bridges, M. W. (1994). Distinguishing optimism from neuroticism (and trait anxiety, self-mastery, and self-esteem): A reevaluation of the Life Orientation Test. Journal of Personality and Social Psychology, 67, 1063-1078.

Schumacker, R. E., \& Lomax, R. G. (1996). A beginner's guide to structural equation modeling. Mahwah, NJ: Lawrence Erlbaum Associates.

Schweizer, K., \& Koch, W. (2001). The assessment of components of optimism by POSO-E. Personality and Individual Differences, 31, 563-574. doi: 10.1016/S0191-8869(00)001616

Shepperd, J. A., Carroll, P., Grace, J., \& Terry, M. (2002). Exploring the causes of comparative optimism. Psychologica Belgica, 42, 65-98. Doi: 10.1348/014466607X236023

Simonds, M. G. (2005). Optimism: A comprehensive psycho-educational program design: Social circumstances, inequalities and health. [Dissertation Abstract] Dissertation Abstracts International: Section B: The Sciences and Engineering, 65(10-B).

Snyder, C. R., Harris, C. Anderson, J. R., Holleran, S. A., Irving, L. M., Sigmon, S. T., Yoshinobu, L., Gibb, J., Langelle, C., \& Harney, P. (1991). The will and the ways: Development and validation of an individual-differences measure of hope. Journal of Personality and Social Psychology, 60(4), 570-585.

Taylor, M. C. (1998). Critical terms for religious studies. Chicago and London: The University of Chicago Press.

Tiger, L. (1979). Optimism: The biology of hope. New York: Simon \& Schuster.

Wallis, R., \& Bruce, S. (1991). Secularization: Trends, data, and theory. In M. L. Lynn \& D. O. Moberg (Eds.), Research in the social scientific study of religion (Vol.3, pp. 1-31). London: Jai Press.

Weinstein, N. D. (1980). Unrealistic optimism about future life events. Journal of Personality and Social Psychology, 39, 806-820.

Weinstein, N. D. (1982). Unrealistic optimism about susceptibility to health problems. Journal of Behavioral Medicine, 5, 441-460.

Weinstein, N. D. (1983). Reducing unrealistic optimism about illness susceptibility. Health Psychology, 2, 11-20. 
Weinstein, N. D. (1984). Why it won't happen to me: Perceptions of risk factors and susceptibility. Health Psychology, 3, 431-457.

Weinstein, N. D. (1989). Optimistic biases about personal risks. Science, 246(8), 1232-1233.

Wiseman, R. (2003). The luck factor. London, UK: Random House.

Yuen, E. J. (2007). Spirituality, religion, and health. American Journal of Medical Quality, 22(2), 77-79. doi: 10.1177/1062860606298872 